\title{
Investigating tidal flexure on an ice shelf using kinematic GPS
}

\author{
DAVID G. VALGHAN \\ British Antartic Survey, Natural Enwironment Research Council, Cambridge CB3 OET, England
}

\begin{abstract}
The positions of ice-stream grounding zones are uniquely sensitive to changes in the mass balance of the ice sheet. Present methods for locating groundingzonc features are either imprecise or require considerable effort in interpretation and so are of little value for change studies. We present a new method which uses the kinematic GPS technique to locate the position of the limit of tidal flexure. The method involves the collection of at least two surface-elevation profiles along the same track through the grounding zone, at different times during the tidal cycle. The elevation profiles obtained coincide upstream of the limit of flexure but diverge downstream of the limit of flexure. Subtracting the profiles produces a tidal-deflection profile which shows directly the response of the ice shelf to the tidal forcing.

We present two examples of the use of this method, both on Rutford Ice Stream, Antarctica. The first is across the grounding zone and shows that the method is capable of measuring grounding positions to around $200 \mathrm{~m}$ precision. The second, taken across an actice shear margin, shows a tidal-deflection profile, with an absence of steps that would indicate the prescnce of fracture planes penetrating from the ice base to sca level.
\end{abstract}

\section{INTRODUCTION}

Several authors (e.g. Wecrman, 1974) have noted that the position of an ice-stream grounding zone is particularly sensitive to the thickness of the ice stream and so to the state of mass balance of the ice-stream/icc-shelf system, or to changes in eustatic sea level. Where the bed beneath an ice stream slopes down towards the sea with a $2^{\circ}$ dip, a fairly typical valuc for 11 est Antarctic ice streams (Bentley, 1987), we could expect a groundingzone movement of around $250 \mathrm{~m}$ to follow a change in ice thickness of $10 \mathrm{~m}$. In many areas, glacier beds slope upward toward the grounding zone, and under these conditions the position of the grounding zone could be eren more sensitive to mass-balance or sea-level changes. Despite the knowledge that a significant alteration in the state of the West Antarctic ice sheet might be first indicated by a change in ice-stream grounding-zone positions, there have been few attempts to locate the positions of current grounding zones with the accuracy that would be required for base-line measurements to which future studies can be compared. To detect a $1 \%$ change in the thickness of a $2000 \mathrm{~m}$ thick ice stream, we should devise methods capable of detecting some feature of the grounding zone to horizontal precision of $250-500 \mathrm{~m}$.

\section{THE FEATURES OF THE GROUNDING ZONE}

Stephenson (1984) and Smith (1991) discussed a typical grounding-zone conliguration with reference to Rutford Ice
Strcam, Antarctica. Smith's schematic diagram Fig. 1) shows that there are several distinct features within the grounding zone: the point at which the glacier loses contact with the bed (the grounding linc); the point at which the glacier first reaches hydrostatic equilibrium; the limit of tidal flexing; and the zone of active strand cracking. Given that the ice in the grounding zone has some flexural strength, the grounding line must be landward of the hydrostatic point. Likcwise, the grounding line must lie seaward of the flexing limit. It seems reasonable that strand cracks should not appear far above the flexing limit since they are themsclics formed by flexing.

The method described here can be used to determine only the limit of flexure. There remains no proven method

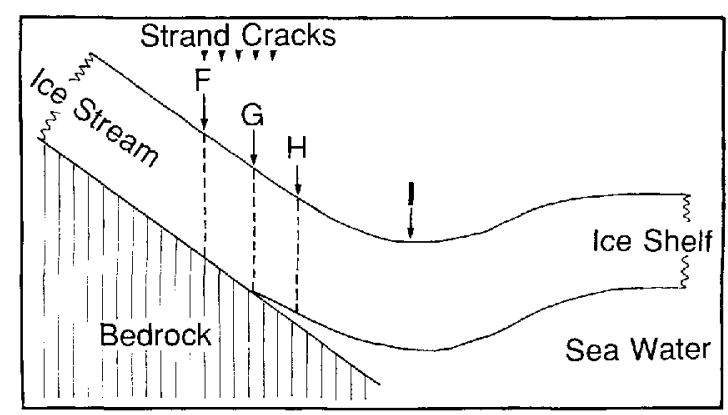

Fig. 1. Schematic grounding zone showing, the limit of fexure $(F)$, the grounding line $(G)$, the hydrostatic point (H), the point of gradient change (I) and the region orer which strand cracks mal be expected. After Smith (1991) and expected for Rutford Ice Stream. 
Table 1. Summary of estimates of the precision of locating grounding-zone features $(\mathrm{F}, \mathrm{G}, \mathrm{H}$ and I defined in Figure I) by the zarious techniques described in section 3 for Rutford lie Stream. * implies that the method is theoretically not capable of locating this feature of the grounding zone

\begin{tabular}{|c|c|c|c|c|c|}
\hline Technique & $F$ & $G$ & $H$ & $I$ & Reference \\
\hline Visible satellite imagery & * & * & $*$ & $500-5000 \mathrm{~m}$ & Swithinbank and others, 1988 \\
\hline Strand cracks & $2000 \mathrm{~m}$ & $*$ & $*$ & $*$ & Stephenson, 1984 \\
\hline Tiltmeter & $1000 \mathrm{~m}$ & $*$ & $*$ & $*$ & Stcphenson, 1984; Smith, 1991 \\
\hline Satellite altimetry & $*$ & $*$ & $\mathrm{~km}$ & $\mathrm{~km}$ & Partington and others, 1987 \\
\hline Optical levelling & $*$ & $*$ & $1-100 \mathrm{~m}$ & $1-100 \mathrm{~m}$ & Smith, 1986 \\
\hline Interferometric $S \Lambda R$ & $50 \mathrm{~m}$ & $*$ & * & * & Goldstein and others, 1993 \\
\hline Radio-echo/seismic & $*$ & $500-1000 \mathrm{~m}$ & * & $*$ & Smith, 1991 \\
\hline Kinematic GPS & $200-500 \mathrm{~m}$ & $*$ & $*$ & $*$ & This study \\
\hline
\end{tabular}

of precisely locating the point of contact with the bed the grounding line), although this can be inferred with limited accuracy from the position of flexing limit and hydrostatic point. Seismic and radio-echo sounding may prove useful in locating grounding lines, but a simple argument invoking Fresncl diffraction shows the limit of the precision available without recourse to complex migration techniques. For Rutford Ice Stream, with a thickness of around $2000 \mathrm{~m}$, seismics at around $200 \mathrm{~Hz}$. would have a footprint of around $260 \mathrm{~m}$, and at $60 \mathrm{MHz}$ around $100 \mathrm{~m}$.

\section{PREVIOUS METHODS OF LOCATING GROUNDING ZONES}

\subsection{Visible imagery}

Visible satellite imagery has been widely used to locate grounding zones for mapping purposes. For example, Swithinbank and others (1988) showed that most of the grounding zones around Filchner Ronne Ice Shell could be mapped from Landsat TM imagery. Unfortunately, the hardest sections to map were those across the ice streams, where the change in surface gradients between grounded and floating ice arc very small. For the image of Recovery Glacier, for example, it would be hard to locate the grounding zone to less than $5 \mathrm{~km}$.

\subsection{Strand cracks}

Strand cracks are fractures in the surface of a glacier that occur in the grounding zone and are caused by the tidal displacement of the ice shelf. Strand cracks have been used as an indication of the position of grounding zones Stephenson, 1984; 'Thomas and others, 1988) but there are limitations on their usefulness for precise location of grounding. Active strand cracks can be as narrow as $1 \mathrm{~cm}$ when fully open and even to an observer on foot they can be difficult to find. During this study on Rutford Ice Stream, many previously obvious strand cracks were completely hidden to the eyc for several days by a fall of stow. Furthermore, active strand cracks were seen to extend over a horizontal distance of $2 \mathrm{~km}$ (equivalent to the ice thickness at this point both upstream and downstream of the hydrostatic point, and their orient-ation was highly variable. It does appear, however, that the most landward strand cracks lic close to the limit of flexure.

\subsection{Tiltmeter}

Tiltmeters capable of measuring angles to tens of microradians have been used on Rutford Ice Stream and Doake Ice Rumples by Stephenson (1984) and Smith (1991) to measure the periodic tilting due to ocean tides within the grounding zone. By modelling the amplitudes of the tilt signals obtained, Stephenson and Smith have estimated the limit of flexure. Unfortunately, this method requires timc-consuming data collection and gives positions for the limit of flexure that are sensitive to the strength parameters used in the models.

\subsection{Satellite altimetry}

Partington and others (1987) used Seasat altimetry to locate the change in surface slope that marks the grounding zone around the lateral margins of Amery Ice Shelf. They used two methods to determine the exact position which agreed to around $600 \mathrm{~m}$. As with visible satellite imagery, this method is suitable only for grounding zones that show a strong change in surface slope.

\subsection{Interferometric SAR}

Recent developments in interferometric analysis of satellite synthetic-aperture radar ( $S A R$ ) imagery show that grounding zones can be located by comparison of phase in images collected at different states of the ocean tide Goldstein and others, 1993). The method promises to be widely applicable but may only yicld the positional accuracy required for change studies when SAR targets (probably corner-cube reflectors) are deployed within the study arca.

\section{KINEMATIC GPS}

\subsection{Background}

The simplest method for determining the trajectory of a moving vehicle by GPS uscs a single GPS recciver to read the coded information on signals from the Navstar satellites. This information contains ephemeris data for 
the satellite transmitting it and clock signals to give the time of the transmission. Simultaneous tracking of four satellites enables the receiver to calculate so-called pseudo-ranges for each of the satcllites, and then the four unknown coordinates: latitude, longitude, ellipsoidal height and time. The calculated position can be recorded dircctly. The precision available from this technique is strictly controlled by the U.S. military and varies from approximately 30 to $100 \mathrm{~m}$.

This precision in the trajectory determination can be improved by a number of methods, the most usual being a differential technique. Here, a sccond GPS receiver records the satellite transmissions simultaneously at at known base station, whilst the rover is travelling. The pscudo-range data from both receivers is processed together after the event. This post-processing allows correction for imprecise broadcast cphcmeris, clock signals and atmospheric/ionospheric variations. In this way, the precision of the rover trajectory may be improved to a few metres.

"Kinematic GPS" Hofmann-Wellenhof and others, 1992), more correctly "carrier-phase GPS" (Remondi, 1985; Minkel, 1989) is now well established and routincly applied in commercial and research applications but has not yet becn widely used in glaciology, although Whillans and others (1990) showed its potential. This method is distinct from either of the previous methods and allows the rover trajectory to be measured to centimetre precision. As in the differential method, two receivers are used, the base station and the rover. The receivers used must be specifically designed for carrier-phase measurement, since they are required to strip away the coded information on the GPS broadcasts and track the relative phase of the carrier signals from the visible satellites. The data recorded in the reccivers consist of the relative phases of signals from each satellite. Changes in the relative phase occur as a result of changes in relative positions of the satellites and changes in the positions of the receivers. Post-processing of the phase data from the two receivers allows the trajectory of the rover to be calculatcd. Hofmann-Wcllenhof and others (1992) gave a brief description of the mathematical aspects of the technique but, given reliable post-processing software, the user need not be fully conversant with it.

The initial phase ambiguity between the receivers can be resolved in several ways. Here it was done by the "antenna-swap" method, in which the receivers record data for a few minutes and then the positions of their antennac are swapped and there is a second period of data recording, and the antennae are returned to their original positions. In this study, two tribrachs on fixed tripod mounts were used. This procedure provides sufficient data to solve the initial phasc ambiguitics.

\subsection{Limitations on use of the kinematic GPS method}

The kinematic GPS method relies on the uninterrupted tracking of the satellite signal and so at least five Navstar satellites must be visible throughout the session. Four are required for position and time solution and one to allow for error identification. In practice, it is wise to choose a period during which seven or more satellites are visible, since this reduces the likelihood of undetected cycle slips and allows the isolation of cycle slips to one satellite. Since there are currently 24 Navstar satellites in the constellation, this is not a very restrictive requirement.

During the 1992-93 season, it was found that if the roving antenna was subjected to persistent ribration, although lock on the satellites signals was not lost, ambiguitics in the solution were found to multiply until the position was unreliable. To reduce this problem, the GPS antenna should be isolated from as much vibration as possible. A similar failure generally occurred if the kinematic session was too long. $A$ practical rule of thumb was found to be that the session should not exceed $2 \mathrm{~h}$.

\subsection{Field procedure}

The field work described below was conducted during the 1992-93 summer field season using Ashtech MD XII receivers and post-processed using the Ashtech GPPS software package. The base-station antenna was mounted on a tripod with its legs buried in the snow and which remained fixed throughout the duration of the experimcnt. The roving antenna was mounted on a $1.5 \mathrm{~m}$ long $3 \mathrm{~cm}$ diameter aluminium pole which was securely fixed and braced on the back of a Skidoo.

The state of lock of the satellite was continually monitored during the sessions and it was found that, given a smooth surface, the Skidoo could be driven at $25 \mathrm{~km} \mathrm{~h}^{1}$ without loss of lock. In areas of particularly high or hard sastrugi this speed was reduced, sometimes to as low as $5 \mathrm{~km} \mathrm{~h}^{\text {l }}$.

By inspection of the calculated trajectory from periods during the session when the Skidoo was stationary, we estimate the uncertainty in position due to the kinematic GPS method alone to be around $\pm 3 \mathrm{~cm}$. This figure includes both the observation error and the uncertainty introduced by the post-processing software. From repeated profiles on grounded icc, we estimate that the method of mounting and driving introduces a further $\pm 8 \mathrm{~cm}$.

\subsection{Investigation of tidal flexure with kinematic GPS}

For the investigation of tidal flexure, we sclected a base station on part of the ice sheet expected to be well above the grounding zone. From here, a route across the grounding zone and out on to the floating ice shelf was cstablishcd. 'The GPS sessions were planned to coincide with the extremes of tide. Several kincmatic GPS profiles were collected along exactly the same route from grounded to floating ice across the grounding zone. Exact coincidence of the profiles was achieved by driving the Skidoo in the track left by the previous session. The tidal-deflcction profiles werc derived by linearly interpolating the irregular elevation data on to a regular spacing. 'These interpolated elevation profiles were subtracted to give the tidal-deflection profile.

Unfortunately, GPS has not yet completely superseded the 'Transit system, which still provides the most accuratc absolute positioning system where no reference station is available. Post-processing with precise satellite ephemeris can yicld $\pm 2 \mathrm{~m}$ in precision (McDonald and Whillans, 1983). After the GPS experiment, the base-station tripods were fixed using Transit Doppler satellite positioning 
Magnavox $1502 \mathrm{~b}, 30$ satellite passes, $\pm 5 \mathrm{~m}$ in order to give the survey the best available absolute position.

\section{EXAMPLES OF RESULTS}

\subsection{An ice-stream grounding zone}

The method described above was first used at the grounding zone of Rutford Ice Strcam (Fig. 2). Stephenson (1984) used tiltmeters and observations of strand cracks to infer the limit of flexing in this area. Hc found that the grounding zone was sinuous and passed around a surface knoll (generated by a bedrock knoll). He used an elastic beam model to extrapolate the tilt data and attempted to map the position of the limit of flexure. Smith (1991) reinterpreted these tilt data and used an improved estimate for the elastic thickness. In places, Smith's estimate of the position of the limit of flexure differs from Stephenson's by $2 \mathrm{~km}$. This highlights the complexity involved in using tiltmeter data to map the limit of flexure and reliance placed on the mathematical model.

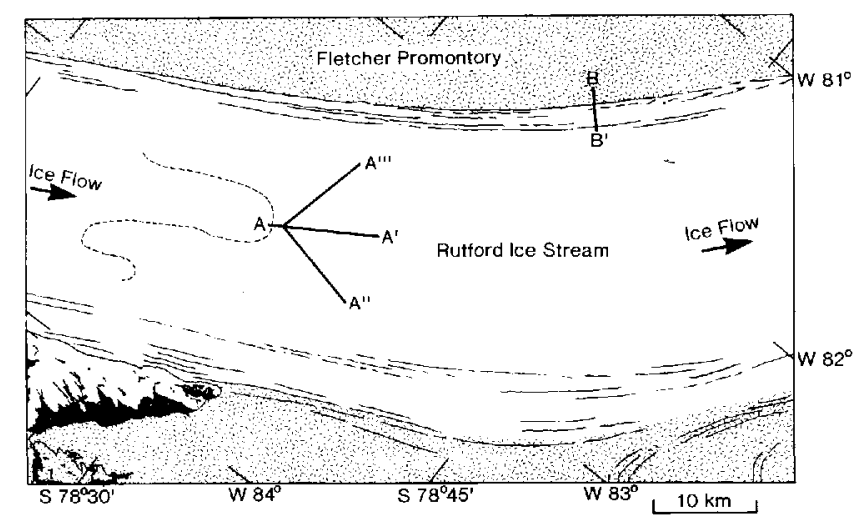

Fig. 2. Grounding zone of Rutford Ice Stream. Bold lines indicate repeated kinematic GPS profiles; $A-A$ shows example 1, the grounding line; $B-B$ show's example 2, the shear margin. The dashed line marks the grounding line giren by Stephenson (1984).

In this study, repeated profiles were made along the lines shown in Figure 2. 'The base station was installed at the summit of the knoll. Figure 3 a shows the result of the repeated profiles along line $\mathrm{A}-\mathrm{A}$ '. 'The tidal-deflection profile (Fig. 3b) shows that the limit of llexure is between 500 and $800 \mathrm{~m}$ along the profile. This is very close to the summit of the knoll, closer than either Smith's or Stephenson's estimates. The other two lidal-dellection profiles, $\Lambda A^{\prime \prime}$ and $A A^{\prime \prime}$ (not presented here), show the same behaviour.

Thesc results were confirmed using tiltmeters placed at the base station and point $\mathrm{X}$. No tidally forced tilting was measured at the basc station. At point $X$, around $400 \mu \mathrm{rad}$ of tidal tilting was recorded, consistent with the tidal-deflection profile.

It is notable that the flexing limit occurs $2000 \mathrm{~m}$ upstream and $50 \mathrm{~m}$ vertically above the hydrostatic point. Supposing that the limit of flexing coincides with the grounding line implies that the strength of the ice sheet supports a considerable hydrostatic anomaly between the hydrostatic point and grounding line. A simple shear-stress
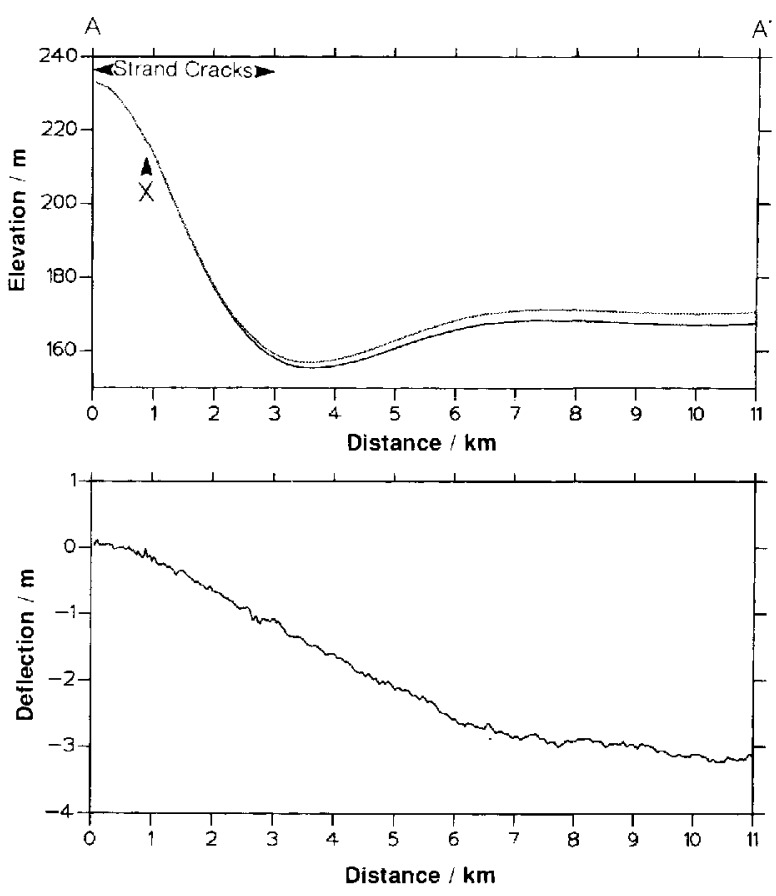

Fig. 3. Repeated elevation profiles and lidal-deflection profile over Rutford Ice Stream grounding line $(A-A)$.

calculation shows that the shear stress requircd to support the hydrostatic anomaly is around $100 \mathrm{kPa}$. This is not excessive when compared with the value of $700 \mathrm{kPa}$ found by Collins and Swithinbank (1968) by the same method to be required to cause full thickness rifting under similar circumstances at the foot of Beardmore Glacier, Antarctica.

The result of the investigation shows that the limit of flexing, and perhaps the grounding line, are very close to the crest of the surface knoll. Indeed, the original schematic presented by Stephenson is, since the ice stream loses contact with the bed at the crest of the knoll, not as thought on a downward-sloping bed. Thus, the grounding line of Rutford Icc Stream is probably pinned at this point. At least on this flowline, it will be insensitive to small changes in thickness or sea level. The grounding zones to either side of the knoll, where the surface gradients appear more gentle, would, on reflection, have better sites to attempt monitoring groundingzone migration.

\subsection{A shear margin}

The sccond investigation site was chosen about $30 \mathrm{~km}$. downstream from the first, across an active shear margin betwecn Ronne Icc Shelf and Fletcher Promontory. At this point, around $400 \mathrm{~m} \mathrm{a}^{-1}$ of movement is taken up by a shear margin $5 \mathrm{~km}$ wide (personal communication from R.M. Frolich), The profiles presented here were collected using a base station on Fletcher Promontory. Crevassing across the shear margin made Skidoo access unwisc and the measurements were performed on skis, causing an increase in the mounting noise to around $\pm 10 \mathrm{~cm}$.

The tidal-deflection profile is given in Figure 4 and clearly shows that the limit of flexure is between 200 and $500 \mathrm{~m}$ along the profile. This point is about $25 \mathrm{~m}$ above the hydrostatic level of the ice shelf.

MacAyeal and others (1986) modelled the dynamics 

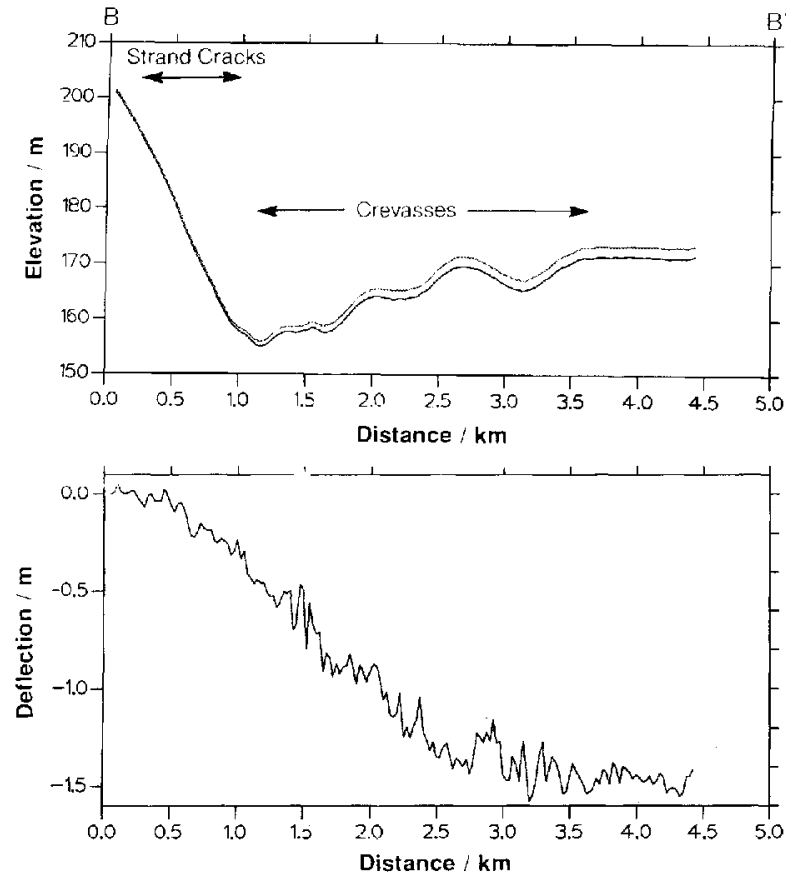

Fig. 4. Repeated elevation profiles and tidal-deflection profile through the shear margin between Rutford Ite stream and Fletcher Promonlory $\left(B^{-}-B^{\prime}\right)$.

of the Ross Ice Shelf using a finite-clement analysis. They found that in order to reproduce the observed velocity pattern for the ice shelf, they had to postulate a very low strength for shear margins. Indeed, they discovered that an acceptable velocity match was obtained cren assuming the shear margins had no strength whatsoever. They suggested that within the shear margin there were fracture plancs cxtending from the ice base to sea level, reducing the competent ice thickness by a factor of 10 . Given this scenario, we would expect the tidal-deflection profile across a shear margin to show a distinct concentration of the tidal flexure in the area of the liactures; a number of en échelon faults would cause a stepped appearancc to the profile. The deflection profile lhrough the shear margin between Ronne Ice Shell and the grounded Fletcher Promontory shows an elastic response very similar to the grounding zone of Rutford Ice Stream. There is no evidence for steps in the tidaldeflection profile or strong localization of the deformation. We conclude that fault planes of the type suggested by Machyeal do not exist in this arca.

\section{SUMMARY}

The collection of repeated kinematic GPS profiles is a quick and efficient method of locating the limit of flexing across a grounding zone. It is more accurate than previous methods and given good conditions can be completed within a day of field work. Further analysis will yield the tidal-dellection profile which can give insight into the behaviour of the ice shect.

The method has shown the location of the flexing limit on Rutford Ice Stream is much closer to the crest of the surface knoll than was previously thought, altering our picture of the grounding-zone geometry. The tidal- deflection profile will in future be analysed in terms of elastic-beam theory.

Applying the method across an actirc ice-shelf shear margin showed the flexing zonc is about $3 \mathrm{~km}$ as compared to $9 \mathrm{~km}$ in the grounding zone. It has still to be detcrmined whether this localization of flexure is due to strain softening of the type described by Jacka and Budd (1989) or if it can be explained solely by thinning of the ice shelf in the shear margin. However, despite much surface crcvassing in the shear margin, the tidal-deflection profile obtained across it shows that the response to the semi-diurnal tide is primarily flexural rather than by faulting.

\section{ACKNOWLEDGEMENTS}

My thanks are due to the U.K. NERG Geophrsical Equipment Pool who loaned the GPS receivers, C. Day for his tireless assistance in the field, and $C$. Doake and A. Smith, who provided advice. Two anonymous reviewcrs have greatly contributed to the quality of the manuscript.

\section{REFERENGES}

Bentley, C. R. 1987. Antaretic ise strams: a review. 7. Geophrs. Res. 92 $\mathrm{B} 94,88438858$.

Contins, I. and C. Swithinbank. 1968. Rilis at the foot ol Beardmore Glacier, Antarcica. Intemational Astociation of Sciontific Iydrolog Publication 79 General Assembly of Bern 1967 Commission of Sncia and lee Report and Discussion, 109-114.

Goldstein, R. M1., H. Engelhardt, B. Kamb and R. M. Frolich. 1993. Satellic radar interferometry for monitoring ice sheet motion: application to an Antaretic ice strean. Sicteme, 262, $1525-1530$.

Hofimann- Wellenhof: B., H. Lichtencgger and J. Collins. 1992. CPS theng and prartire. Wien. New York, Springer-Yorlag.

Jacka, T. H. and W. F. Budd. 1989. Isotropic and anisotropic flow relations for ice dynamics. Am. Glacol.. 12, 8184.

Mactreal, D. R., S. Shabtaic, G. R. Bentley and S. D. King. 1986. Formulation of ice shelf dymamic boundary conditions in troms of a Coulomb rheology. 7. (reophys. Res., 91 B8:, 81778191.

MeDonald, J and I, M. Whillans. 1988. Comparison ol results from Transit satcllite tacking. Amm. Glaciol. 11.83-88.

Minkel, 1).H. 1989. Kincmatic GPS land survey description of operational test and results. f. Smoring Eng. 115 1 : 121-137.

Partington, K.C., W. Cudlip, N.F. MCIntre and S. King-tlele. 1987. Mapping of Amery los Shelf, Antarctica, surface leatures by satellite altinetry, Ann. Glaciol., 9, 183188.

Remondi B. II. 1985. Global positioning susten carrier phase: description and use. Bull. Getot. 59.361-377.

smith, A. M. 1986. Ice rumples on Rome Ice Shelf, Antareticat. B). Antart. Swz. Bull., $72,47.52$.

Smith, A. 11. 1991. The use of tilmeters to study the dymamios of Antare tic ice-shelf grounding lines. F. Glaciol. $37,125 i, 51-58$.

Stephenson, S. N. 1984. Glacier flexure and the position of gromnding lines: measurements by tilmeter on Rutford Ice Streatur, Antarctica. Am. Glaciol. 5. 165-169.

Swithinbank, C., K. Brunk and J. Sicrers. 1988. A glaciological map of Filehner-Rome Ie Shelf, Antarcica. Am. Glaciol, 11, 150-155.

Thomas, R. H., S. V. Stephenson, R. A. Bindscharller, S. Shabtaie and C. R. Bentley, 1988. 'Thiming and groumding-line retrat on the Ross Ice Shelf, Antarctica. . Lim. Gitciol.. 11. $16 \overline{5} 172$.

Wertman, J. 1971. Stability of the junction of an ice sheet and an ioc shelt: F. Gilaciol., 1367,311

Whillans, I. M., C. vander Veen and Yi-Hsing Tseng. 1990. Application of the Global Positioning System in Antarctica. Antart. $j . \tau^{-} . S$. $25(2), 69$.

The accuracy of references in the text and in this list is the responsibility of the author, 10 athom queries should be addressed. 